\title{
Machiavelli's Biblical Accuracy: A Note of Rectification
}

\author{
SEBASTIAN DE GRAZIA
}

When an author is one whose work is great and controversial, and the critic one whose stature lends weight to his remarks, a note of correction where called for is in order.

In chapter 26 of the Prince Machiavelli writes,

the sea has opened; a cloud has guided your path; the rock has poured forth water; here it has rained manna. ${ }^{1}$

Leo Strauss, in Thoughts on Machiavelli, does not question Machiavelli's rendering of the above events into Italian; he notes that Machiavelli's "sequence differs from the sequence of the Mosaic miracles." 2 To be able to say this means that the "sequence of the Mosaic miracles" must stand revealed somewhere, and the obvious place is in the Book of Exodus. There one finds the order to be sea, cloud, manna and rock (Exodus 14.16, 21, 22; 14.21; 16.4; 17.6), and so, in fact, Machiavelli's sequence is different: rock and manna are inverted. Machiavelli does not say, however, that these words of his comprise a translation or citation of Exodus. He was familiar with other parts of the Bible as well, and may have taken the order of events from one of its stylized recitals. For example, Psalm 78 (77 in the Vulgate), verses 13-24, uses similar expressions and reports the sequence in Machiavelli's order: sea, cloud, rock, and manna. Machiavelli was acquainted with the Psalms and was also likely to have heard this text in the liturgy. It may be, too, that he takes the sequence from a sermon or other oral version. We know he heard Savonarola discourse on Exodus ${ }^{3}$ perhaps the Friar had one day departed from the written sequence as preachers are notoriously apt to do.

The point is small. Machiavelli is using the passage - even if he had direct recourse to the Bible - to set a mood for the times. Strauss does not say that the discrepancy has a purpose. Elsewhere he notes that there was only one reference to the Bible in the Prince, earlier in Chapter $13 .{ }^{4}$ No doubt he meant a direct reference by name, and then not a reference to the Bible but to the Old Testament specifically. 
Strauss writes also that "Machiavelli says there [in the last chapter] that God was a friend of Moses, Cyrus and Theseus. The description is applied to Moses with greater propriety than to Cyrus and Theseus." 5 Strictly speaking, Machiavelli writes, "nor was God more a friend to them than to you," meaning by "you" whomever he was exhorting in Chapter 26. As to the greater propriety of applying the phrase to Moses, Strauss' second sentence above does not make clear whether it is himself or Machiavelli who is making the judgment of propriety. If it is himself, Strauss does not explain the propriety or even cite the relevant phrase. If it is Machiavelli, Strauss' remark can be regarded as comment rather than criticism, since Machiavelli must certainly have put Moses first for his status in Exodus (33.11) as the man to whom the Lord spoke face to face as one speakingad amicum suum. Whether Machiavelli placed Cyrus second and Theseus third because the Bible commends the former pagan without mentioning the latter seems plausible but highly speculative and need not concern us here.

A more direct charge by Strauss involves the same sequence of biblical events mentioned earlier. "Machiavelli calls the God-wrought contemporary events which resemble certain Biblical miracles not 'miracles' but 'extraordinary' events 'without example': he thus denies the reality of those Biblical miracles and therewith, for an obvious reason, the reality of all Biblical miracles." 7 Precisely speaking, Machiavelli does not use the term "extraordinary" or "extraordinary events"; he uses estraordinarii, to wit, "extraordinaries," a word rare in English but not obsolete, especially in the plural. Nor does he leave this noun unqualified, as he writes of "estraordinarii. . condotti da Dio." This is language that supports and complements the Bible, conveying rather than denying the idea that God orchestrates the several events described in these verses.

Exodus, moreover, does not call these events "Mosaic miracles," as does Strauss, or even plain "miracles." Actually, the Latin miraculum in this meaning is alien to the entire Vulgate, the only Old Testament available to Machiavelli. The equivalent for this "miracle" in the King James translation is typically signum or prodigium. None of these terms, however, appear in the relevant passages from Exodus. In another book, the Lord does refer to these events as signa, saying, "my miracles which I did in Egypt and in the wilderness" - but this is Numbers ${ }^{8}$ not Exodus. In Exodus 34:10, the King James Version refers to miracles in the following way: "Before all thy people I will do marvels [signa], such as have not been done in all the earth, nor in any nation." 9 The phraseology bears out Machiavelli's "without example" and - no mean feat makes his language at once imaginative and circumspect. ${ }^{10}$

Other criticism by Strauss (and there is much) of Machiavelli's religious statements turns on questions such as God's relation to fortune or Machiavelli's intention in relation to his rhetoric, rather than on his 
accuracy. The last criticism from Thoughts on Machiavelli to be examined - itself a sort of rhetoric - involves Strauss' strictures on a word that appears in the one mention of the Bible by name in the Discourses (iii, 30). Machiavelli, wrote Strauss, had read the Bible "judiciously" (p. 163) and "expects the readers who have been trained by him, to read the Bible 'judiciously"" (p. 183). Strauss did not define the Italian word nor give the original passage, leaving the reader to conclude that the accuracy of the rest of the sentence, or indeed of any reference to the Bible, was suspect.

In the statement where the word occurs Machiavelli is talking about Moses whom he greatly admires as a lawmaker and saviour of his people. He knows that others admire him too, but do not generally associate the prophet with mass violence and family extermination. To illustrate that even great men of religion may in the course of their mission have to resort to violence, Machiavelli writes, "And whoever reads the Bible sensibly, will see that Moses was forced. . to kill numberless men."11 Exodus 32:27-29 and Numbers 31:13-18, 35 attest to the accuracy of Machiavelli's biblical reference. The word that Machiavelli here uses for "sensibly" is sensatamente, which comes from the late Latin sensatus, meaning provided with sense, intellect or understanding. Machiavelli uses the word once in this context. Strauss in various biblical contexts throughout his book repeats the reference to "judicious" reading of the Bible, keeping the term set off always by ironic quotes. ${ }^{12}$ Yet anyone can still read and see that in Exodus those 3,000 brothers, friends and neighbours were killed on orders of Moses. An earlier use of sensatamente in the Discourses seems to have escaped Strauss. ${ }^{13}$ There (in i.23) Machiavelli employs the word in the same sense as above. Opening a new paragraph in the chapter he continues a discussion of the military defense of mountain passes: "And whoever reads sensibly all the [pertinent] histories, will find very few capable captains to have tried to hold similar passes." 14 Comparing this with the later passage (Discourses iii.30) one notes that the form of the subject clause is identical and the words themselves almost identical. ${ }^{15}$ Clearly this is the same common usage of the term, employed this time in connection with events reported by Livy and other historians. By beginning the phrase with the pronounced "E chi..." and by word for word repetition, Machiavelli confirms he means the intelligent reading of valued sources.

We may turn, finally, to the only express reference to the Old Testament in the Prince. To illustrate that you should put trust in your own weapons since the weapons of others slip off your back, weigh you down or bind you, Machiavelli writes,

I want also to bring back to memory a figure of the Old Testament suited to this point. When David volunteered to Saul to go and combat Goliath, the Philistine challenger, Saul, to give him spirit armed him with 
his arms, which David as soon as he had them on threw them off, saying that with them he could not demonstrate his own value and anyway he wanted to encounter the enemy with his sling and with his knife. ${ }^{16}$

Strauss notices this passage, of course, asserting that "Machiavelli completely disregards what the Bible says in the context about Divine assistance to David." 17 Surely Machiavelli would be glad to strengthen his thesis by pushing agency back to the ultimate cause in a proposition such as: Trust in your own arms and you trust in Me. But here he modestly tries to establish only the first half of the proposition. Anyway, Strauss does not question, as he might, Machiavelli's accuracy in reporting David's arms. ${ }^{18}$

In sum, these criticisms by Strauss do nothing to detract from Machiavelli's accuracy. ${ }^{19}$ Scholars of all kinds may make errors or get carried away by their arguments. Machiavelli is no exception, nor are his critics.

Rutgers University

Notes

1 el mare si è aperto; una nube vi ha scòrto el cammino; la pietra ha versato acqua; qui è piovuto la manna. Quotations from The Prince and Discourses are taken throughout from the edition by Sergio Bertelli, Machiavelli: Il Principe e Discorsi sopra la prima deca di Tito Livio (Milan: Feltrinelli, 1960), unless otherwise noted.

2 (Glencoe, Ill.: Free Press, 1958), p. 309, n. 41.

3 Letter to Ricciardo Becchi, 9 March 1498.

4 Thoughts, p. 329, n. 10.

5 Thoughts, pp. 71-2.

6 né fu a loro Dio piú amico che a voi.

7 Thoughts, p. 73. Also see pp. 145, 199, 204, 309, n. 41, 322, n. 143, 332, n. 55.

8 Numbers 14:22. Vulgate: signa quae feci in Aegypto et in solitudine.

9 Note that even here the King James did not use "miracles." In the Vulgate: signa faciam quae numquam visa sunt super terram, nec in ullis gentibus.

10 Prince 26: extraordinarii sanza exemplo, condotti da Dio. Among the expressions chosen by translators to put this phrase into modern idiomatic English are the following: "miraculous and unprecedented things wrought by God" (J.B. Atkinson, 1976), "extraordinary things without example conducted by God" (L.P.S. de Alvarez, 1980), "extraordinary, unexampled leadings from God" (R.M. Adams, 1977), "unparalleled signs from God" (T.G. Bergin, 1947), "unheard of wonders. . .performed by God" (G. Bull, 1961), "unexplained wonders. . .performed by God" (L. Ricci, 1921), "extraordinary and unexampled means prepared by God" (A. Gilbert, 1958).

11 Discourses (iii.30). E chi legge la Bibbia sensatamente vedrd̀ Moisè essere stato forzato, a volere che le sue leggi e che li suoi ordini andassero innanzi, ad ammazzare infiniti uomini, $i$ quali non mossi da altro che dalla invidia si opponevano a' disegni suoi. A comma after sensatamente is carried by the G. Mazzoni and M. Casella edition of the Discourses: Tutte le opere storiche e letterarie di Niccolò Machiavelli (Firenze: G. Barbèra, 1929), p. 92. 
12 Thoughts: "reading the Bible judiciously" (p. 51), "read the Bible judiciously" " (p. 51 also), "read the Bible "judiciously"" (p. 163), "to read the Bible "judiciously"” (p. 183), "infinitely more of such "judicious readings" " (p. 305).

13 In L.J. Walker's magisterial two volume edition of The Discourses of Niccolo Machiavelli, (New Haven: Yale University Press, 1950) the repetition of the term is hidden by a different translation in each case: "with appreciation" in 1.23 (I, 269) and "with discernment" in iii.30 (I, 547).

$14 E$ chi leggerd sensatamente tutte le istorie, troverrd pochissimi virtuosi capitani avere tentato di tenere simili passi, .... .

15 All told, other differences in the two clauses indicate that the earlier historical passage is slightly more emphatic. Using the future tense of leggere makes it a little more suggestive that not everybody does read Livy or other historians; placing the adverb before the noun mildly increases the force of the adverb; while starting the paragraph with the clause (if one is to trust the paragraphing of the Mazzini edition) lends it the slight stress of position. These and other subtle considerations can easily be made but they seem too uncertain to warrant conclusions.

16 Voglio ancora ridurre a memoria una figura del Testamento Vecchio fatta a questo proposito. Offerendosi David a Saul di andare a combattere con Golia, provocatore filisteo, Saul, per darli animo, l'armò dell'arme sua: le quali, come David ebbe indosso, recusò, dicendo con quelle non si potere bene valere di se stesso, e perd voleva trovare el nimico con la sua fromba e con il suo coltello.

17 Strauss, Thoughts, pp. 329-30, n. 10.

18 On the question of David's knife, see L. Arthur Burd, ed., Niccolo Machiavelli: II Principe (London: Clarendon Press, 1891), p. 275, n.9.

19 See Walker's high praise for Machiavelli's accuracy, Discourses, II, pp. 311-12. 